\title{
PUBLIC LOSS IN THE ACTIONS AND ACTS OF TAXATION FROM THE VIEWPOINT PUBLIC FISCAL LAW
}

\author{
Yasemin TAŞKIN ${ }^{1}$
}

\author{
Salim Ateş OKTAR ${ }^{2}$
}

\begin{abstract}
Basic assurance of taxpayers against fiscalist behaviours of officers responsible for tax transactions and inspections and member of commissions is tax jurisdictions. As a means protecting the taxpayer against such transactions of public officers cause some kind of unjust enrichment on behalf of taxpayer. Furthermore, the means of protecting public interest against unjust enrichment on behalf of tax payer is fiscal law which includes public expenditure law besides tax law. It can be expected that the taxpayers spend effort to obtain their rights under the motive of protecting their personal interests. Coming across such an effort is difficult in case of public interest violation. As a result of acting highly generous of officers responsible throughout the taxing process at times can reducing tax revenues and public resources. In case being reflected the defective will of public officers on administrative procedures and actions on public loss has been occured in the meaning in the Law no. 5018 titled Law of Public Fiscal Administration and Control. The decision procedure and action which cause the public loss whether a requirement of the task or not will be inquired within the frame of fiscal inspection law. If a loss matches up with the type defined in the Law no. 5018, an obligation of the indemnity will be occurred. In addition the sanctions of discipline and criminal law will be implemented.
\end{abstract}

Keywords: Public Loss, Taxation, Taxation Action, Public Fiscal Law, Fiscal Law, Tax Law.

JEL Code: K34, K39.

\section{Introduction}

Public loss concept can be defined in the broad sense as every kind of damage has been done disservice to the society. A relatively restricted definition can be given as the damage brought on the public property. The one most restricted and associated with the public expenditure law is taken part in the first paragraph of the item 71 of the Law no. 5018 titled Law of Public Financial and Control as "preventing an increase or causing a decrease in the public resource as a result of a decision, action or act that violates the legislation and that items from intention, fault or disregard of public officers". At the same item some presumptions have taken place to be based on to be determined the public loss such as making payments in excess of the amount determined as the price of works, goods or services; making payments without receiving the goods or without having the work done or service provided; making excessive or groundless payments in the expenditure in the form of transfers; purchasing goods, works or services or to have them done for a price higher than their market price; no imposing, accuring or collecting the revenues of the administration in accordance with the legislation; making payments although not envisaged in the relevant legislation.

\footnotetext{
1 Assoc. Prof., Dr., Istanbul University, Faculty of Economics, Department of Public Finance, taskiny@istanbul.edu.tr

2 Prof., Dr., Istanbul University, Faculty of Economics, Department of Public Finance, oktarat@istanbul.edu.tr
} 
Taxation actions which are administrative acts express the actions assessment, notification accruement (precautionary accural) and collection. It is possible to take into account the case conciliation in this context.

In this paper, the reductions on tax assessments to be performed on the tax bases appreciated and defined by tax administration, accruement and collection stages; tax loss arising from the lack of appreciation of tax base and the reductions are not incompatible with the qualification and conciliation and principle of proportionality through the conciliation process (post-assessment and pre-assessment) will be discussed against the public loss provisions of the Law no. 5018 .

\section{Discretionary Power and Its Limits on Which Tax Administration Has on Appreciations and Definitions and The Other Actions Which Effects Tax Claim}

Despite as a result of the legality principle, 'dependent power' has been adopted in the tax law, it is seen that a broad "discretionary power" has also given to the administration ${ }^{1}$. The situation the law orders to administration to make a decision is named "dependent power", on the contrary, if the administration has a freedom on acting, that is "discretionary power".

An example can be given, according to the article 112/5 of Tax Procedure Law, no. 213;

"If taxes have to be refunded in accordance with tax acts do not refund in three months beginning from the month in which have been completed all the information and documents by the taxpayer, an interest equals to the postponement interest rate in the Law No: 6183 from the end of three months period to the date of notification will be paid to the taxpayer with the tax has to be refunded."

In accordance with those imperative provisions, the tax administration do not have any discretionary power on to refund or not to refund to the taxpayer. Consequently, the power administration has here is a dependent power.

On the other hand, below example can be given for discretionary power. According to the article 17/1 of the Tax Procedure Law, no. 213.

"Persons who cannot fulfil tax duties in time because they are in a difficult situation are given a proper additional delay by Ministry of Finance as long as not to exceed the legal period, in case the legal period less than a month, as long as not to exceed a month.

To be given that delay;

1. Person who wants delay has to apply by a written request.

2. Reason is expressed in that written request has to be admittable.

3. Collection the tax has not been taken a risk when the delay has given."

The situation is different here. A discretionary power has given to the tax administration for the subjects the reliability of the excuse which is shown by the applicant and in case the delay has given, collecting tax would be under risk or not.

The constitutional basis of discretionary power of administration has been taken place in the Constitution article $125 / 4$ is as below.

"Judicial power is limited to the review of the legality of administrative actions and acts, and in no case may it be used as a review of expediency. No judicial ruling shall be passed which restricts the exercise of the executive function in accordance with the forms and principle prescribed by 
tax, which has the equality of an administrative action and act, or which removes discretionary powers."

The provision which is taken place under the "types of administrative law suits and the borderline of the judicial powers" with title of article 2/2 of Administrative Jurisdiction Procedure Law no. 2577 line as;

"Judicial power is limited to the review of the legality of administrative actions and acts. The administrative courts cannot do the appropriateness establish judicial ruling shall be passed which restricts the exercise of the executive function in accordance with the forms and principles prescribed by law which has the quality of an administrative action and act, or which removes discretionary powers"

reflects above mentioned constitutional provision.

Being made appreciations and determinations of tax bases which are basis of extraordinary tax assessments properly to the subjective-individual conditions of tax payers; not being made appreciations and determinations of tax bases at higher levels than required are necessary to be obeyed the tax payers' rights. In case violating the tax payers' rights, although applying the administrative processes to remove those violations is possible the main authority is judicial authority to remove that violation.

Tax payer can display two alternative behaviors against opposite taxation acts. Firstly, tax payer cannot notice that the act causes a violation of right and suffers from an additional tax and/or penalty burden. Secondly, tax payer notices and attempt to remove the violation. First possible behavior will cause an unjust enrichment behalf public treasury. As a conclusion of the second behaviour, when removed unlawfulness of the act by nullity, the result of the first behavior will be removed partially or totally.

The subject has not been discussed enough in this context is appreciation and determination of tax bases remain lower levels than required of subjective individual status of tax payers and its consequences. Several provisions exist in the tax codes and many sources of tax law in order to be prevented this conclusion.

Those provisions can be encountered many places from assessment and penalty to conciliation; from tax payers' tasks and evaluation to the tax inspection private regulations are also encountered some places. For example, according to the article 76 under title line "loyalty to the declaration" in the Tax Procedure Law no. 213, the tax base, has been appreciated cannot be lower than tax payers' return in which has been already given in appreciation related with tax bases had been declared before by tax payers.

Public loss which emerges from the faulty wills of tax officers reflects on taxation actions and act, has been unbalanced the equilibrium personal interest-public interest in the unlawful way against the second one.

\section{Going Over the Border in Using Power Against the Public}

There are miscellaneous compensation mechanisms which tax payers can apply against negative conclusions of overusing of discretionary power and exceeding the border which drawn by law in the dependent power. Besides judicial way, administrative ways of which numbers have been increasing day by day can supply resolution to remove violations of rights. 
Public opinion of taxation has much more knowledge about the conclusions of taxation actions and acts against tax payers' interest than against public treasury. In particular under the effect of being highly discussed tax payers' rights recently, the optimal equilibrium point of personal interest and public interest has been started to be discussed.

Tax payers' rights of course important. The tendency in the World is to be adopted tax payers' focused approach today. On the other hand, the reason of existence and functions of taxation should not to be forgotten. Therefore, transactions decreasing of tax and penalty bases of appreciation commissions, inspection officials and conciliation commissions during appreciation and determination of tax and penalty bases are necessary to be considered in the way of public focused approach from the viewpoint of principles and rules of the Public Expenditure Law.

Taxation is the main tool to be produced and supplied to the society of needed resources. Assessment and collection taxes completely in time have crucial importance for public and budget finance. Malfunctions, deficiencies and lags in levying taxes will inevitably cause problems to fulfil the public needs (Oktar, 2019: 321).

In this context, it should be discussed that a loss which requires indemnification arises or not while being used the dependent power and especially discretionary power whether public resources have been affected in negative way as a consequence of the administrative actions and acts.

\section{Public Loss and Its Indemnification Issue}

Actions and acts are made of related public officers should be examined according to the article 71 in which regulated the public loss of the law, in case the public treasury suffers a loss as a consequence of being used the dependent power faulty and unlawful and also the discretionary power arbitrary to be defined whether mentioned a public loss in the sense of the Law no. 5018 and can be claimed back from related, public officers.

It is clear that being made appreciations of the tax base less than required by the inspection officer and being reduced in tax penalty more than required by conciliation commission cause a decrease or obstacle an increase in public resource. Nevertheless, defining of this result indicates a public loss or not has been required a detailed examination².

Some subjective and objective circumstances have to be exist to be mentioned public loss.

Making decisions, actions and act which are violating the legislation as a result of faulty wills (intention fault tor disregard) of public officers.

Causing a decrease or obstacle an increase in public resource as a result of those decisions, actions or act $^{3}$.

In the article 71, some presumptions have taken place of public loss. One of those presumptions which has crucial importance for this paper is "no imposing, accruing or collecting the revenues of the administration in accordance with the legislation, making payments although not envisaged in the relevant legislation".

In accordance with those provisions, except committing fraudulent actions, presidents and members of appreciation commissions because of appreciation of tax base less than required; tax inspectors because of determining tax bases less than required and conciliation commissions 
because of over reductions in taxes and penalties more than required will be responsible to pay indemnification for public loss.

Appreciations and determinations of tax bases and reductions make by conciliation commissions must make by considering cases in the right way and using objective criteria. Appropriately usage of discretionary power of administration is the need of principle of equality when decisions, actions and acts which exceed the border of power cause loss of public resources, public loss will be emerged.

The public loss determined as a result of control, audit, examination, final sentence of trial shall be collected from the relevant persons together with its legal interest to be calculated according to the related legislation as of the date of the loss emerged.

The penalties stipulated herein will be imposed by the relevant top managers. Penalties shall be collected by deducting one fourth of all payments earned by the relevant persons including all kinds of salary, allowance, pay raise and compensation beginning from the month following imposition of the penalty and without requiring any further judgement (Law no. 5018, article 73).

The liability has not been remain limited with the Compensation Law. Due to the decisions, actions or acts that violates the legislation which have been created by faulty will some results in the sense of the Disciplinary Law and the Penal Law may be emerged.

\section{Conclusion}

Despite a discretionary power has given to administration for additional ex-officio, administrative assessment and collection acts and tax and penalty reductions made by conciliation commissions, beside principles of legality, equality and justice; the limit of this power in the public expenditure law are provisions on public loss of Public Financial Management and Control Law no. 5018.

In case, while appreciating and determining of tax bases and while being used discretionary power not to be considered the features of events and acting against the principle of proportionality, it is going to be implemented the provisions of public loss. The power cannot be used without limit and arbitrary, even if the limit of the power has not clearly been defined.

The needed research and examination must be completely done and achieving the real tax base amounts are obligatory at taxation act and pre-act. When considered the provision; no imposing, accruing or collecting the revenues of the administration in accordance with the legislation and making payments although not envisaged in the relevant legislation one of the determinants of the public loss and whether decreasing which is occurred of the reasons except the will of tax payer in the tax burden has been emerged from the faults of public officers, presidents and members of the conciliation commissions, a public loss in the sense of Law no. 5018 which has to be paid by responsible persons and furthermore, it has some other conclusions within the frame of the disciplinary and penal law. 


\section{Notes}

1. See for the discretionary power of the public administration, Gerçek A. (2006). The Discretionary Power of Administration in Turkish Tax Law, Ankara, Yaklaşım and Üstün, Ü. S. (2007). The Discretionary Power of Administration in Turkish Tax Law, Ankara, Turhan.

2. See Taşkın, Y. \& Oktar S. A. (2012). "Some Notes on Public Loss and Some Problems Encountered in the Higher Education Institutions", http://alomaliye.com/2012/09/17.

3. On the subject public loss can be referred these books: Şişman, G. (2017). Public Loss from the Point of Tax Claim at the Court of Accounts Jurisdiction, Ankara, Seçkin and Turguter, N. (2012). Explanation of the Public Loss, Ankara, Ankara University Press.

Public resource has been defined at the article 3/1-g of Law no. 5018 as, "public revenues including those acquired through borrowing and to movable and immovables deposits receivables and rights and all kinds of valuables, that all belong to the public".

\section{References}

Gerçek, A. (2006). The Discretionary Power of Administration in Turkish Tax Law, Ankara, Yaklaşım.

Gözler, K. \& Kaplan, G. (2018). Administrative Law Courses, 14th Printing, Bursa, Ekin.

Oktar, S. A. (2019). Tax Law, 14th Printing, İstanbul, Türkmen.

Şişman, G. (2017). Public Loss from the Point of Tax Claim at the Court of Accounts Jurisdiction, Ankara, Seçkin.

Taşkın, Y. \& Oktar S. A. (2012). Some Notes on Public Loss and Some Problems Encountered in the Higher Education Institutions, http://alomaliye.com/2012/09/17.

Turguter, N. (2012). Explanation of the Public Loss, Ankara, Ankara University Press.

Üstün, Ü. S. (2007). The Discretionary Power of Administration in Turkish Tax Law, Ankara, Turhan. 